\title{
Call for more coordination of Gulf war syndrome research
}

Washington. Efforts to identify the so-called 'Gulf War Syndrome' affecting US troops who served in the Gulf War largely consist of badly designed and poorly coordinated studies that are unlikely to provide useful results, according to the US Institute of Medicine (IoM).

An IoM panel describes the $\mathbf{5 0}$ or so separate public and private studies now under way as well-intentioned. But it claims that they are "intrinsically unsuiteffects of the Gulf War", because of the methods used to select participants and collect data.

The IoM panel, chaired by John Bailar of McGill University, Montreal, Canada, found that most of the studies were piecemeal in nature, and that some had "several fundamental problems". Most lacked proper controls to compare, for example, the health of the Gulf veterans being studied with a control group of other subjects.

"Overall, there has been a serious lack of adequate attention to the design of individual studies," the panel found, while the failure to coordinate the studies was able for systematic study of the health

\section{an "even more serious" weakness.}

Part of the problem has been a lack of coordination between the main government departments involved, namely Defense, Veterans' Affairs, and Health and Human Services. The IoM calls for Vice-President Al Gore to chair a committee to coordinate their efforts, and to involve leading epidemiologists.

But Bailar says that Defense and Veterans' Affairs officials who saw the report before publication appeared receptive to its central message. "What's been done is characteristic of the early stages of recognition of any new or newly recognized disease," he says. That phase has now come to an end, he adds, and large-population studies are now needed.

An investigation by the National Institutes of Health last year found no firm evidence for the existence of a 'Gulf War syndrome', and Bailar is noncommittal. He admits that there are "a significant number of veterans who are sick and suffering", but adds that the nature and specificity of their illnesses remained unknown.

Colin Macilwain

\section{Ballot urged on ageing centre plans}

San Francisco. Animal-rights and environmental activists have stalled the construction of a \$100-million centre for multidisciplinary research on ageing in California, claiming that plans for the centre are too ambitious.

The Buck Center for Research in Aging is the result of eight years of planning following a court decision that $\$ 5$ million of the funds of the Buck Trust should be devoted annually to an international centre on ageing.

The trust supports a variety of social services and environmental groups in Marin County, north of San Francisco. Bulldozers had begun preparing land for construction of the new center when opponents collected almost 19,000 signatures to put the project to a local ballot. Now county officials will have either to rescind their support of the Buck Center, or ask local citizens to vote on whether to build the project.

The centre hopes to attract scientists to carry out basic, clinical and social policy research on ageing. The first five years of work are planned to be devoted to the ageing brain, with projects in Alzheimer's disease, Parkinson's disease, cognitive problems and depression.

The board of the centre expects researchers to supplement its \$5-million annual budget with grants from the National Institutes of Health, support from private philanthropists and agreements with corporations.
But local environmentalists are objecting to the project's size and location. The centre owns 488 acres of land and the project would eventually include a 355,000-square-foot research and education complex, a commercial centre and about 120 condominiums

Officials say that they plan to build on only 6 per cent of the land, and to landscape or otherwise alter slightly more than half the parcel. But local residents say that plans to stabilize the side of Mount Burdell (the mountain that the site backs on to) in order to manage radioactive and infectious waste safely would destroy an important greenbelt.

Animal-rights activists argue that the centre's plans to study only rodents or similar animals are likely to change. Others complain that the financial bonds needed to fund the centre could put other programmes funded by the Buck Trust in financial jeopardy.

Craig Perrin, coordinator for the Committee to Save Mount Burdell, which has led the protest campaign, says that the community would have preferred a centre focused solely on human clinical studies, regarding basic research as outmoded.

But a spokeswoman for the centre says that it has worked with the local community to find ways to mitigate the development's impact, and is confident that local citizens will approve the plan.
Blood transfusion system comes under fire in Canada

Montreal. A group of international experts has criticized the operation of Canada's blood transfusion system and warned that safety could be "seriously compromised" unless deficiencies in its procedures are corrected. The experts were called in by a commission of inquiry — headed by $\mathrm{Mr}$ Justice Horace Krever - set up last spring to review the country's blood transfusion system.

In its report, the expert group claims in particular that the responsibilities of the organizations making up the system - the Canadian Red Cross Society, the Bureau of Biologics (the federal regulatory agency), the Canadian Blood Agency (the funding body) and various public health departments - are poorly defined, and cause conflict among the agencies.

The group, which was chaired by Kenneth D. McClatchley, professor of pathology at the University of Michigan, Ann Arbor, in the United States, also criticizes the overuse of blood and blood products, understaffing, and a lack of expertise at the Bureau of Biologics.

Its overall verdict is that Canada's blood system is as safe as that of other industrialized countries. But although procedures for collecting blood and manufacturing blood products at regional centres are "satisfactory", they are nonetheless "fragile".

The experts recommend a restructuring of the system to eliminate conflicts among the various agencies, and to define their responsibilities for ensuring safety. The Bureau of Biologics should be given more resources to enable it to monitor safety, adds the report, while the Red Cross needs to improve planning and management.

Furthermore, the scope of research should be enlarged, it says, from mainly investigator-led studies of basic medical problems to wider issues of health-systems research. In particular, research should include evaluating strategies to improve safety and efficiency in blood collection and delivery.

The Red Cross has accepted most of the group's conclusions, in particular those that would rebuild the public confidence in the system damaged, as in many other countries, by the contamination of blood supplies with human immunodeficiency virus in the mid-1980s.

The recommendation that regulatory procedures should be improved has also been supported by the Canadian Hemophilia Society. According to the society's president, Durhane Wong-Reiner, many senior employees at the Bureau of Biologics have quit because of frustration with its structure, although the bureau itself says it intends to double its staff to 24 .

David Spurgeon 